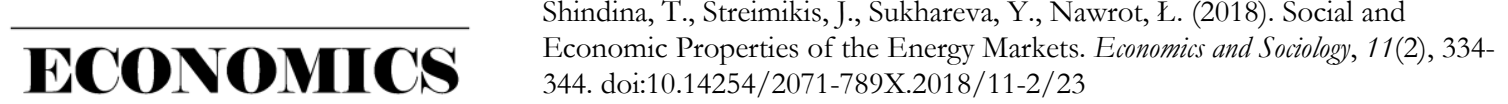

(e)ialogy

\section{SOCIAL AND ECONOMIC PROPERTIES OF THE ENERGY MARKETS}

\author{
Tatyana Shindina, \\ National Research University \\ "Moscow Power Engineering \\ Institute", \\ Moscow, Russia, \\ E-mail: ShindinaTA@mpei.ru \\ Justas Streimikis, \\ Lithuanian Institute of Agrarian \\ Economics, Vilnius, \\ E-mail: \\ justas.streimikis@gmail.com
}

\author{
Yevgenya Sukhareva, \\ National Research University \\ "Moscow Power Engineering \\ Institute", \\ Moscow, Russia, \\ E-mail: \\ SukharevaYevV@mpei.ru \\ Lukasz Nawrot, \\ Poznan University of Economics \\ and Business, \\ Poznan, Poland, \\ E-mail: l.nawrot@ue.poznan.pl
}

Received: March, 2018

1st Revision: April 2018

Accepted: May 2018

DOI: $10.14254 / 2071-$

789X.2018/11-2/23

JEL Classification: $\mathrm{P} 28, \mathrm{Q} 41$

\begin{abstract}
Consumer properties of the thermal and electric energy which are the products at energy markets yield interconnections that have significant impact on the laws of energy consumption. When physical or price restrictions of the thermal energy supply are present at the power markets, the shortage of energy can be compensated by an increase in electricity consumption. At the same time, it appears that the interconnection of heat and electricity consumption largely determines the model of ower supply organization.

Our paper analysed social and economic properties of the energy market. We show that in the case of separate production of heat and electric energy, these products yield the properties of substitutes for the consumers at the energy market. Our results show that heat and electric energy are interchangeable and the increase in the cost of one of them leads to its replacement by the other. At the same time, we find that for the countries with the welldeveloped combined production of heat and electric energy from the same energy source (the so-called cogeneration) which is typical for countries with a cold climate, the interrelationship between heat and electricity acquires a complementary nature, and the rise in prices for one commodity will not necessarily lead to a significant increase in demand for the other.
\end{abstract}

Keywords: energy markets, power supply, consumers, heat, electricity.

\section{Introduction}

Electricity and heat are used at energy markets, but they represent a special type of consumer goods with continuous production and consumption. Under the conditions of developed market relations, these goods are characterized by the complex nature of their 
consumer properties' interrelationships. On the one hand, they are substitute goods in relation to each other, with the distinctive feature of increased demand for one product along with an increase in price for another. with such interchangeable goods, a shortage or price increase of thermal energy leads to an increase in demand for electricity and, consequently, to an increase in its price later. On the other hand, with a certain model of organization of energy supply to consumers, electricity and heat can also have the properties of complementary goods, when the growth in demand or price for one product will also lead to an increase in demand and price for another one.

The most common case of organization of consumer energy supply, when electricity and heat can have consumer properties of complementary energy products, is organization of their joint production at a combined heat and power plant in an inseparable, combined cycle. In this case, heat and power supplied to the consumer are simultaneously produced at a combined heat and power plant in a single technological process. The growth in demand for heat energy, produced in conjunction with electricity in a combined cycle, is achieved by reducing fuel costs, which can be more than 2 times lower when produced on a separate thermal source (boiler house). Accordingly, increased demand for combined heat energy will also lead to increased demand for the electricity generated in the same cycle of production. And vice versa, if the demand for combined electric power is reduced in the power system, this will also lead to a reduction in the production of combined heat energy.

Lack of adequate accounting and analysis of the complex interconnection of consumer properties of electricity and heat leads to the emergence of cross subsidies in the energy sector of various countries, which has a devastating impact on the energy product markets and leads to the introduction of inefficient solutions, both in production and in consumption of energy. Ultimately, this causes a constant increase in the cost of energy products' provision to consumers, despite the efforts made by states aimed at increasing the economy of energy production and reducing fuel costs, including the efforts to increase the share of combined electricity and heat production.

\section{Literature review}

Recently, many countries have been actively discussing the issue of expanding the share of cogeneration of energy products, caused by the need for a significant reduction in fuel consumption in the energy sector (Konova et al., 2012; Lisin et al., 2014; Zlyvko et al., 2014; Wissner, 2014; Lisin et al., 2016; Sayegh, 2017; Werner, 2017; Samarina, 2018; Simionescu et al., 2017). It should in turn lead to an increase in the complementary relationship between electricity and heat as goods in energy markets (Kasperowicz et al., 2017; Pinczynski et al., 2016; Streimikienè et al., 2016; Strielkowski et al., 2016; Ushakov and Kharchenko, 2018). Figure 1 that follows shows the assessment of the potential for cogeneration development in various countries of the world including BRICS countries, United States, Japan and major EU Member States.

Nowadays, the combined production of energy products with the organization of centralized heating for consumers is used to solve energy supply problems in many countries. At the same time, the share of cogeneration in the total volume of electricity and heat production ranges from $5 \%$ to $50 \%$, depending on the country. At the same time, practically all countries have a significant reserve for increasing energy efficiency by increasing the share of cogeneration in the production of heat and electricity.

The greatest distribution of cogeneration and district heating in countries with cold climatic conditions, which is due to a large number of heating days, associated with a prolonged winter and autumn-spring period. However, centralized heat supply based on 
cogeneration sources also found application in the southern countries (especially in Italy and France), which is connected with the peculiarities of planning the development of local power supply systems for consumers and the existing significant deficit of fuel resources.

Cogeneration is widely represented in Russia, China, and in the EU countries (the „old“ Member States represented by Germany, United Kingdom, France, and Italy). In the United States and Canada it has not been widely used despite the presence of territories with a cold climate. In Russia the share of central heating is $80 \%$, China $-55 \%$, Denmark $-40 \%$, Finland $-35 \%$, in the USA $-4 \%$, Canada $-1 \%$. It is the scale of the development of centralized heat supply systems, in the first place that determine the potential for the use of cogeneration and its possible role in the energy supply of consumers.

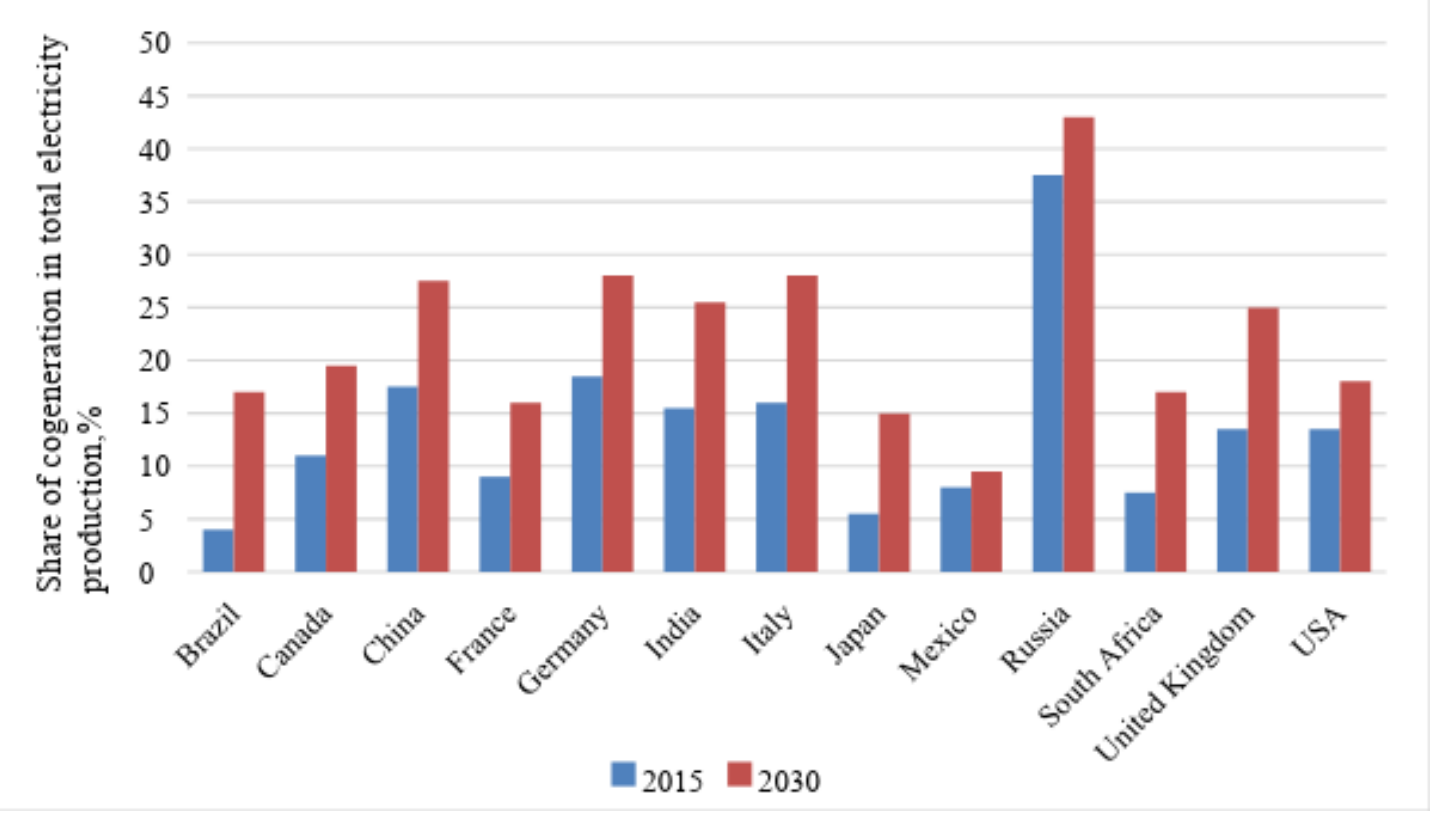

Figure 1. Assessment of the potential for the development of combined electricity and heat production in various countries of the world

Source: Own results based on European Commission (2015), European Commission (2018a), and International Energy Agency (2018).

Russia is characterized by the world's largest district heating system, covering more than $70 \%$ of the population (Lisin et al., 2015; Stennikov et al., 2016; Lisin et al., 2018; Ushakov et al., 2017). Such a large-scale development of the centralized heat supply system is conditioned by a long heating season in the country ( $80 \%$ of the territory is located in severe climatic conditions). Its main production facilities are concentrated in large cities and settlements.

Combined energy production is carried out at the CHP (Combined heat and power plant) with a share of about $37 \%$ in the volume of energy production. The average functional time of the CHP is about 30 years, which affects their economy. Despite this, the fuel utilization factor at the CHP is about $52 \%$. The share of natural gas is $72 \%$, coal $-22 \%$ in the structure of fuel consumption for heat production.

Now, the development of cogeneration production in the country is not attractive to investors, which is due to the loss of CHP in the electricity and heat markets. The reason for this is the conducted reform of the electricity market, not taking into account its relationship 
with the heat market. It significantly reduced the competitiveness of CHP in both markets, despite their profitability (Naoumova, 2015; Lisin et al., 2016).

The deterioration of heat networks and the inefficient use of cogeneration sources led to a significant increase in the cost of thermal energy, which had a considerable impact on consumers due to the high social importance of heat supply. The heating costs of the population make up about $50 \%$ of the cost of housing and communal services and continue to grow. Since the heat market is one of the largest single-product markets in the country, the consequences of this process have a significant impact on the economy. Thus, some of the population's expenses are shifted to the industrial consumer through cross-subsidization, and also covered from the budgets of regions and municipalities.

Unfavourable trends in the development of cogeneration are associated with a discrepancy between the centralized heat supply systems - created during the planned economy - and the market principles of the energy complex functioning. Despite this, cogeneration and district heating will continue to occupy a leading place in the structure of production and supply of energy products to consumers.

China has the second largest district heating system in the world, covering $70 \%$ of the territory and $17 \%$ of the country's population (Gong et al., 2015; Li et al., 2015). The main users of centralized heating systems are Northern provinces.

The share of cogeneration in heat production within the framework of centralized heat supply systems is about $47 \%$, in the production of electricity $-20 \%$. In recent years, the length of thermal networks has been constantly growing, which leads to an increase in the volume of the market for thermal energy based on centralized heat supply systems by more than $5 \%$ per year.

The country implements the target program for the development of cogeneration based on CHP, which led to the commissioning and reconstruction of $90 \%$ of the installed capacity of the CHP plant over the past few decades. Thus, cogeneration in the country is characterized by a sufficiently low coefficient of wear and high efficiency. At the same time, the main fuel in the production of heat is energy coal (90\%) (Wu et al., 2014; Lei et al., 2018). Similar to Russia, most of the district heating systems in the country are formed on the basis of a highcapacity CHP plant. At the same time, they are primarily focused on heating without providing hot water services. Local authorities are responsible for the organization of heat supply. The market of heat energy is liberalized, and many small enterprises are involved in the provision of heat supply services. This led to the fact that heat networks and heat sources develop in the absence of coordination with the plans and obligations of municipalities to develop central heating.

Relatively high rates of industrial growth in the country contribute to the widespread distribution of central heating systems based on CHP. Recently, centralized heat supply has covered the eastern and southern provinces of the country (Jiangsu, Zhejiang, etc.). The introduction of the mandatory development of municipal plans for the development of central heating systems and the consolidation of heat supply enterprises will increase the economic attractiveness and scale of the development of central heating on the basis of the CHP and will contribute to increasing the efficiency of joint generation of heat and electricity.

EU Member States are characterized by a different concentration of cogeneration in the production of energy products, which is caused by the difference in the history of the development of national energy, strategic priorities, the availability of natural resources and climatic conditions. Figures 2 and 3 reflect trends in the development of centralized heat supply and cogeneration systems based on it in these countries. 


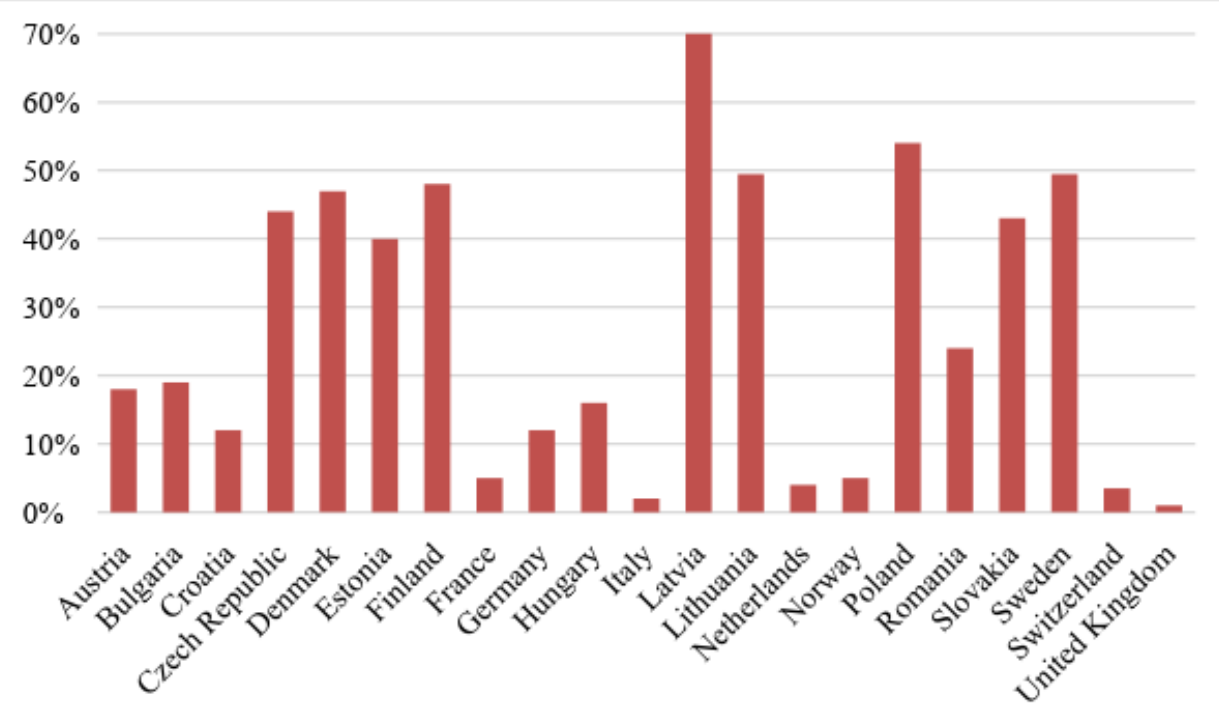

Figure 2. The share of centralized heat supply systems in the volume of heat production Source: Own results based European Commission (2018a; 2018b).

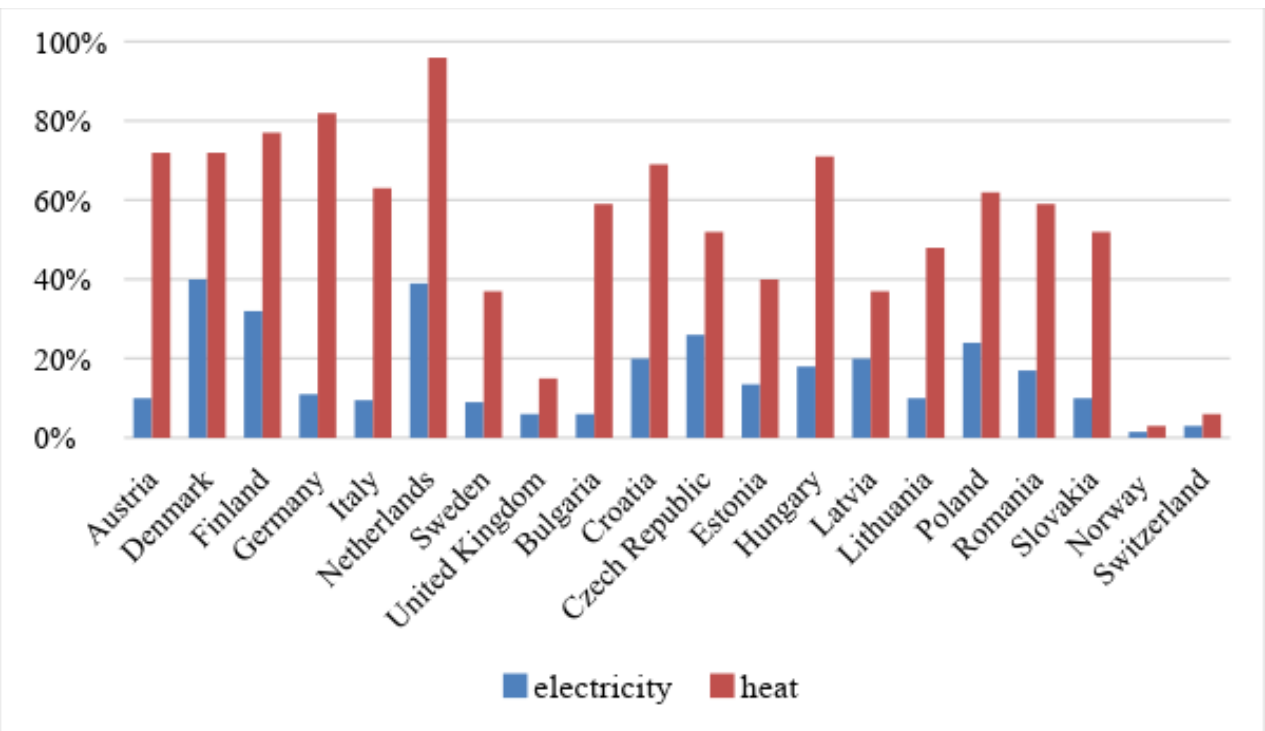

Figure 3. Share of electricity and heat produced by cogeneration power plants Source: Own results based European Commission (2018a; 2018b).

The largest share of cogeneration in the structure of energy production belongs to the countries of Eastern and Northern Europe. Compared to other EU countries, their power systems produce approximately $10 \%$ more electricity at cogeneration plants, and their share in electricity production reaches an average of $20 \%$. At the same time, the share of centralized heat produced in the cogeneration mode is much more significant and varies from $35 \%$ to 95\% depending on the country.

In general, in the EU, cogeneration maintains its stable position in the electricity and heat markets. In a number of countries (Germany, Austria, Italy, Hungary), combined power production is growing supported by the national programs for the development of small-scale cogeneration plants (mini-CHP) and the formation of new schemes for central (district) 
heating (Aste et al., 2015; Keles et al., 2016; Webb, 2015; Comodi et al., 2017; Sayegh et al., 2017; Tvaronavičienè et al., 2018).

The potential for the development of cogeneration in the countries of the western, southern and central parts of the EU is related to the development and implementation of new district heating schemes based on mini-CHP plants and a qualitative increase in heat production in the combined cycle. For the eastern part it is optimization of the existing legacy of post-Soviet times in the form of high-capacity thermal power plants and based on them large central (district) heating systems.

\section{Methodological approach}

The substitutional and complementary nature of the consumer properties of heat and electricity, reflecting their interchangeability and complementarity for consumers, can be investigated based on the analysis of the cross-elasticity coefficient:

$$
E_{Q N}\left(P_{Q}, \Delta P_{Q}\right)=\frac{\Delta V_{N}\left(\Delta P_{Q}\right)}{\Delta P_{Q}} \cdot \frac{P_{Q}}{V_{N}\left(P_{Q}\right)}=V_{N}^{\prime}\left(P_{Q}\right) \frac{P_{Q}}{V_{N}\left(P_{Q}\right)}, E_{Q N}>0, \Delta P_{Q}=\Delta, \Delta \rightarrow 0
$$

where $P_{Q}, \Delta P_{Q}$ - the price of thermal energy and its increment, $V_{N}, \Delta V_{N}$ - volume of electricity consumption and its increment.

In this case, the cross-elasticity coefficient reflects the change in the volume of demand for electricity along with a change in the price of heat. If electricity and heat for the consumer are in the energy market by substitute goods, the rise in heat prices will lead to a significant increase in electricity consumption. In case if electricity and heat are for the consumer complementary goods, the increase in the heat price will cause either a reduction in energy consumption for two energy products at once, or the preservation of the established consumption structure.

Thus, in order to analyse the cross-elasticity of demand for electricity with a change in the heat price, several correlation and regression models were developed (Table 1).

Table 1. Results of the heat and electricity demand and prices model

\begin{tabular}{|c|c|c|c|c|c|c|}
\hline \multirow{2}{*}{ Parameter } & \multicolumn{6}{|c|}{ Country } \\
\hline & Russia & Germany & UK & Italy & China & France \\
\hline \multicolumn{7}{|c|}{ Correlation dependence of the change in demand for heat from the price of its supply } \\
\hline The price of supply of heat energy & $-0,38$ & $-0,25$ & $-0,85$ & $-0,91$ & $-0,77$ & $-0,87$ \\
\hline \multicolumn{7}{|c|}{ Correlation dependence of the change in demand for electricity from the price of its supply } \\
\hline The price of supply of electricity & $-0,20$ & $-0,17$ & $-0,56$ & $-0,59$ & $-0,49$ & $-0,14$ \\
\hline \multicolumn{7}{|c|}{$\begin{array}{c}\text { Correlation dependence of the change in the ratio of prices for electricity and heat to the ratio of } \\
\text { their consumption volumes }\end{array}$} \\
\hline $\begin{array}{l}\text { The ratio of prices for electricity } \\
\text { and heat }\end{array}$ & 0,12 & $-0,24$ & $-0,57$ & 0,25 & $-0,29$ & $-0,72$ \\
\hline
\end{tabular}

Source: Own results.

The first two models represented in Table 1 reflect the stochastic relationship between the price of energy products and the volume of consumption. The last model demonstrates the effect of changes in the ratio of prices for electricity and heat to a change in the ratio of 
volumes of consumption of these energy products. The relationship between heat and electricity demand and prices is described by the non-linear pair correlation coefficient.

\section{Results and discussions}

In order to analyse the complex relationship between the consumer properties of heat and electricity, an analysis of time series reflecting the dynamics of changes in the volume and cost of energy production relative to each other for different countries of the world was conducted (Figures 4 and 5).

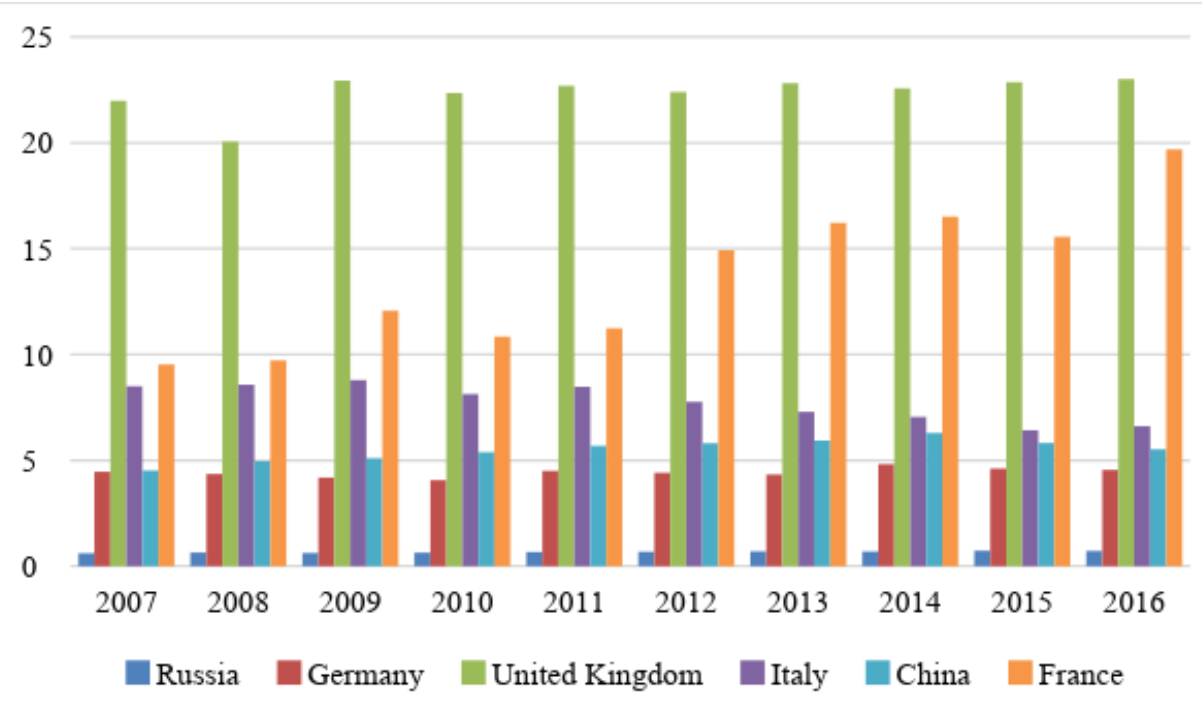

Figure 4. The ratio of electricity consumption to heat for various countries Source: Own results.

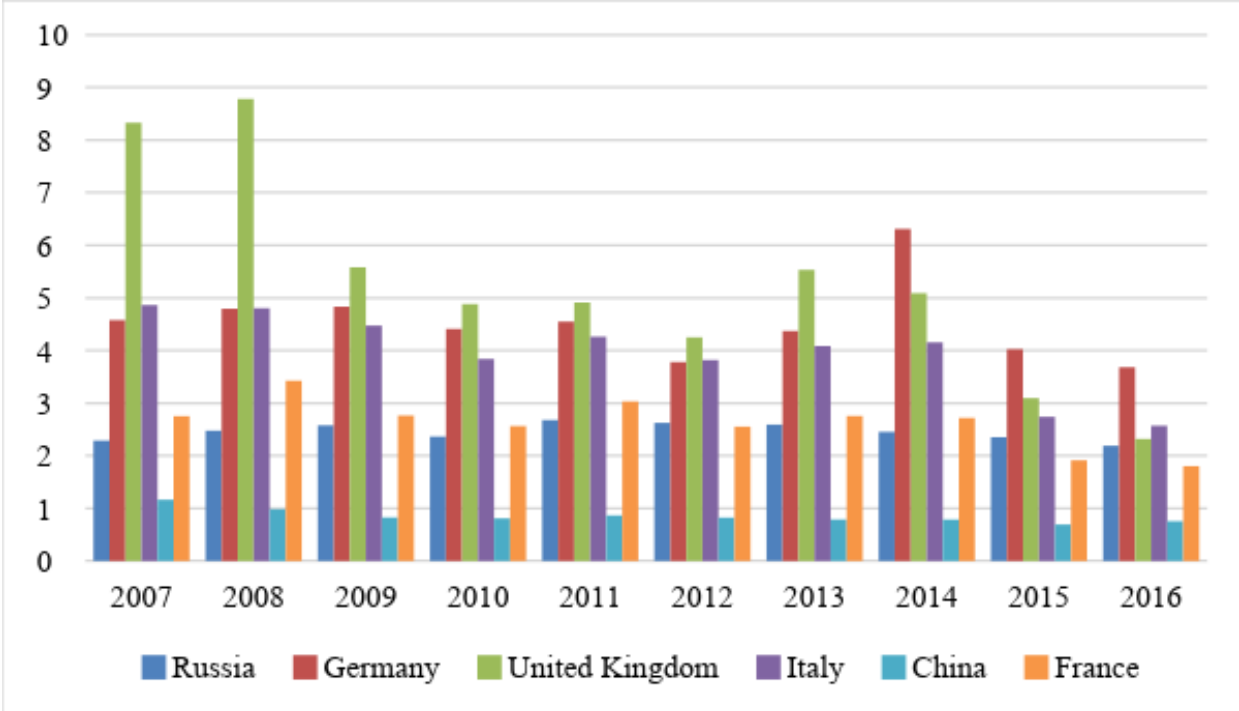

Figure 5. The ratio of prices for electricity and heat for various countries Source: Own results. 
For EU countries and China, electricity consumption volumes exceed the amount of heat consumption, while for Russia the opposite is observed. This is due to the country's harsher climate, as well as the pattern of energy consumption with a significant proportion of the population in it. wide spread of cogeneration production also contributes to it, which, with the technologies used in the country, usually produces heat several times more than electricity to ensure significant fuel economy.

For all countries, except Italy, there is an increase in consumption of electricity volumes over heat consumption. Such significant differences in the dynamics of the proportions of electricity and heat consumption for a given country are due to the process of reducing industry (thus increasing the share in the consumption structure of the population) and implementing a program for connecting city residents to central heating systems to make heating more affordable for the consumer.

In case the majority of countries in our sample, electricity consumption volumes increase comparing to heat consumption, while the proportions of prices for these energy products, on the contrary, decrease. This is due to the growing competition in the electricity markets and the formation of global sale markets, while local heat markets are monopolistic. Thus, heat prices in the world grow more than electricity prices. In some countries, such as China, the cost of heat for the consumer has already exceeded the cost of electricity.

A partial exception to the revealed regularity is the dynamics of the proportions of prices for electricity and heat in Russia, where the correlation between energy prices is roughly the same. This is explained by the wide spread of cogeneration and, correspondingly, by the significant dependence of heat and power production, which leads to the fact that with the growth of costs for the production of one of the products, costs will also increase for the development of another. Another reason for this phenomenon is the weak development of competition in the electricity market, which is characterized by oligopolistic nature, with strict state regulation of prices for heat. Figure 6 that follows shows a joint analysis of changes in the proportions of volumes and prices for heat and electricity.

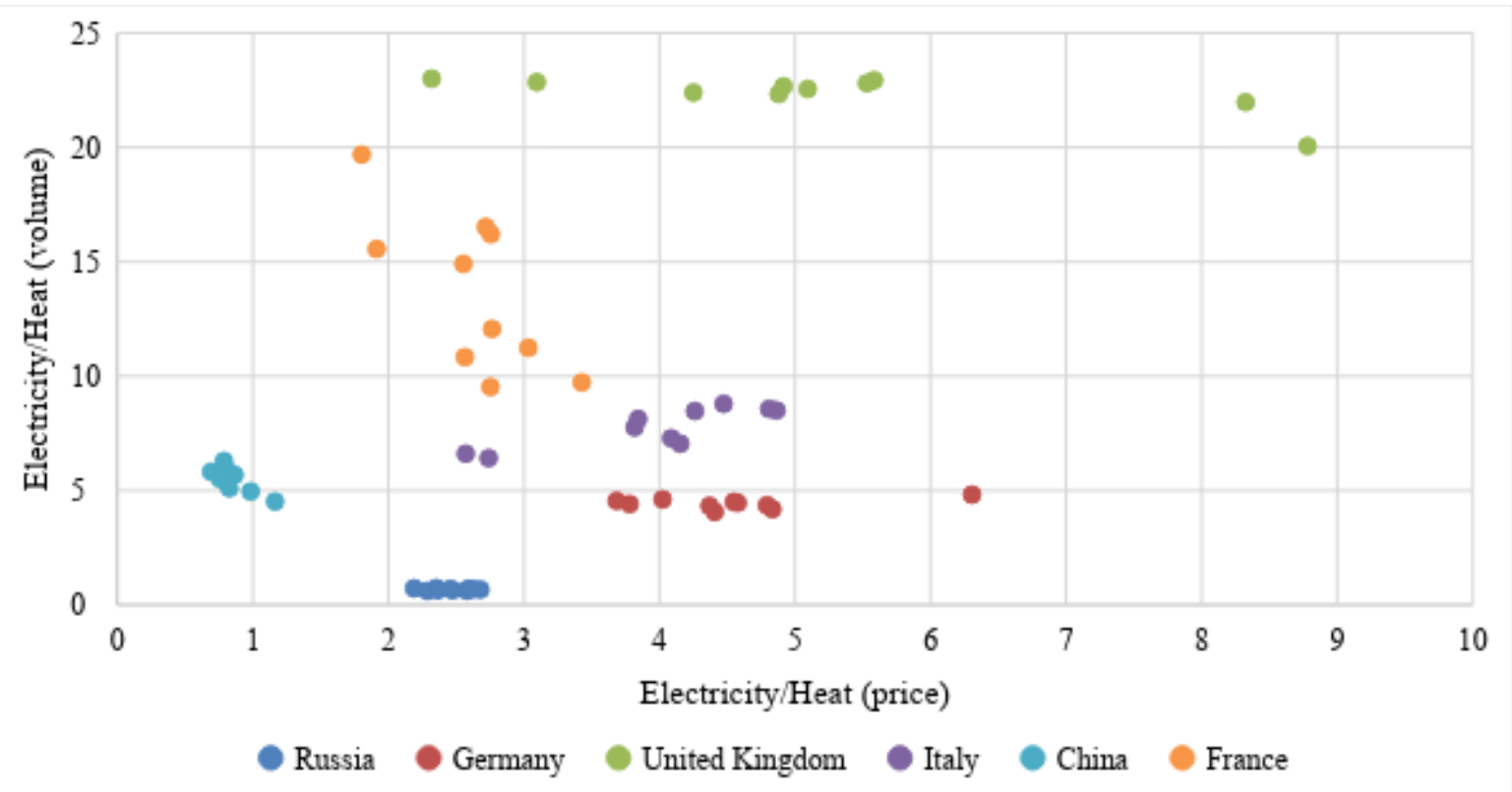

Figure 6. Analysis of changes in the proportions of volumes and prices for heat and electricity for selected countries

Source: Own results. 
The dependencies shown in the graph (Figure 6) allow us to conclude that for countries with a developed and developing centralized heat supply system and combined heat and power production, an increase in heat prices comparing to electricity does not lead to a significant reduction in heat consumption due to substitution of electricity by consumers. In this case, such countries include Russia, China, Germany and Italy. Particularly indicative are the results for Russia, where consumption of heat exceeds electricity consumption, and cogeneration is most widely represented in the structure of energy production. And, on the contrary, for England and France, there is a clear dependence of the reduction in the volumes of heat consumption with a decrease in the price for electricity. For England, this dependence is smoother due to less availability of heat for consumers from heat supply systems, which leads to a significant range of changes in electricity prices.

\section{Conclusions and discussions}

The study of cross-elasticity of demand for heat and electricity for various countries of the world represented by BRICS countries, USA, Japan and selected EU Member States demonstrated that thermal and electric energy as goods on energy markets are characterized by a complex interconnection of their consumer properties that have a significant impact on the rules of their consumption. The increase in the price for heat can lead to an increase in demand for electricity, or not significantly affect its change. It was revealed that in many respects this is due to the model of organization of energy supply of consumers adopted in the country.

With a separate model of production and supply of consumers with thermal and electric energy adopted in the country, these products acquire the properties of substitute goods for the consumer in the energy market, when, with an increase in cost per one energy product, it can be replaced by another. At the same time, for countries with a well-developed joint production of heat and electricity at one energy source and centralized power supply to consumers, the interrelationship between heat and electricity acquires a complementary character, and the increase in the price of one product does not lead to a significant increase in demand for another.

The explanation of the relationship between the consumer properties of electricity and heat is particularly important for understanding the rules of heat and electricity consumption in order to develop an efficient energy policy in the country and a model for the development of the national energy system. The admitted omissions in the energy policy lead to crosssubsidization of production and consumption of heat and electricity and the destruction of energy markets. As a result, consumers' expenses for self-sufficiency in energy production are constantly growing, despite the efforts made by the state to improve the economy of energy production and reduce fuel costs.

\section{References}

Aste, N., Buzzetti, M., \& Caputo, P. (2015). District heating in Lombardy Region (Italy): Effects of supporting mechanisms. Sustainable Cities and Society, 14, 43-55. https://doi.org/10.1016/j.scs.2014.07.006.

Comodi, G., Lorenzetti, M., Salvi, D., Arteconi, A. (2017). Criticalities of district heating in Southern Europe: Lesson learned from a CHP-DH in Central Italy. Applied Thermal Engineering, 112, 649-659. https://doi.org/10.1016/j.applthermaleng.2016.09.149. 
European Commission (2015). European Cogeneration Roadmap 2015 [accessed 01-032018], online: http://www.code2-project.eu/wp-content/uploads/CODE-2-EuropeanCogeneration-Roadmap.pdf.

European Commission (2018a). EU countries reports of the national potential of cogeneration and district heating [accessed 01-03-2018], Available online: https://ec.europa.eu/energy/en/topics/energy-efficiency/cogeneration-heat-and-power.

European Commission (2018b). EU energy trends to 2030. [accessed 01-03-2018], Available online:

https://ec.europa.eu/energy/sites/ener/files/documents/trends_to_2030_update_2009.pdf

Gong, M., Werner, S. (2015). An assessment of district heating research in China. Renewable Energy, 84, 97-105. https://doi.org/10.1016/j.renene.2015.05.061

International Energy Agency (2018). Global CHP/DHC Data. [accessed 01-03-2018], Available online: http://www.iea.org/chp/data/globalchpdhcdata-currentbaseline/

Kasperowicz, R., Pinczyński, M., Kumar Tiwari, A., Nawrot, Ł. (2017). Reengineering of electricity market monitoring. Economics and Sociology, 10(4), 175-188.

Keles, D., Bublitz, A., Zimmermann, F., Genoese, M., Fichtner, W. (2016). Analysis of design options for the electricity market: The German case. Applied Energy, 183, 884901. https://doi.org/10.1016/j.apenergy.2016.08.189.

Konova, O., Komarov, I., Lisin, E. (2012). The relevance of power generating capacities based on the combined cycle power plants of high power. Czech Journal of Social Sciences, Business and Economics, 1(1), 101-109. https://doi.org/10.24984/cjssbe.2012.1.1.11.

Lei, N., Chen, L., Sun, C., Tao, Y. (2018). Electricity market creation in China: policy options from political economics perspective. Sustainability, 10, 1481-1496. https://doi.org/10.3390/su10051481.

Li, H., Sun, Q., Zhang, Q., Wallin, F. (2015). A review of the pricing mechanisms for district heating systems. Renewable and Sustainable Energy Reviews, 42, 56-65. https://doi.org/10.1016/j.rser.2014.10.003.

Lisin, E., Lozenko, V., Komarov, I., Zlyvko, O. (2015). Business competitiveness of Russian power plants in current market situation. Transformation in Business \& Economics, 14, 557-574.

Lisin, E., Sobolev, A., Strielkowski, W., Garanin, I. (2016). Thermal efficiency of cogeneration units with multi-stage reheating for Russian municipal heating systems. Energies, 9(4), 269. https://doi.org/10.3390/en9040269.

Lisin, E., Marishkina, Y., Strielkowski, W., Streimikiene, D. (2017). Analysis of competitiveness: energy sector and the electricity market in Russia. Economic Research - Ekonomska Istraživanja, 30(1), 1820-1828. https://doi.org/10.1080/1331677X.2017.1392887.

Lisin, E., Shuvalova, D., Volkova, I., Strielkowski, W. (2018). Sustainable development of regional power systems and the consumption of electric energy. Sustainability, 10(4), 1111-1121. https://doi.org/10.3390/su10041111.

Lisin, E., Strielkowski, W. (2014). Modelling new economic approaches for the wholesale energy markets in Russia and the EU. Transformation in Business \& Economics, 13, 566-580.

Naoumova, I. (2015). Liberalization of the electricity market in Russia: the tool of the growing democracy or dictatorship? In: Emerging Markets and the Future of the BRIC Nations, Edward Elgar Publishing, Massachusetts, 97-110.

Pinczynski, M., Kasperowicz, R. (2016). Overview of electricity market monitoring. Economics and Sociology, 9(4), 153-167. https://doi.org/10.14254/2071-789X.2016/9-4/9. 
Samarina, V., Skufina, T., Samarin, A., Ushakov, D. (2018). Alternative energy sources: Opportunities, experience and prospects of the Russian regions in the context of global trends. International Journal of Energy Economics and Policy, 8(2), 140-147.

Sayegh, M. A., Danielewicz, J., Nannou, T., Miniewicz, M., Jadwiszczak, P., Piekarska, K., \& Jouhara, H. (2017). Trends of European research and development in district heating technologies. Renewable and Sustainable Energy Reviews, 68, 1183-1192. https://doi.org/10.1016/j.rser.2016.02.023.

Stennikov, V. A., Iakimetc, E. E. (2016). Optimal planning of heat supply systems in urban areas. Energy, 110, 157-165. https://doi.org/10.1016/j.energy.2016.02.060.

Strielkowski, W., Lisin, E., Tvaronavičienè, M. (2016). Towards energy security: sustainable development of electrical energy storage. Journal of Security \& Sustainability Issues, 6(2), 235-244. https://doi.org/10.9770/jssi.2016.6.2(4).

Simionescu, M., Albu, L. L., Raileanu Szeles, M., \& Bilan, Y. (2017). The impact of biofuels utilisation in transport on the sustainable development in the European Union. Technological and Economic Development of Economy, 23(4), 667-686.

Štreimikienè, D., Strielkowski, W., Bilan, Y., Mikalauskas, I. (2016). Energy dependency and sustainable regional development in the Baltic states: A review. Geographica Pannonica, 20(2), 79-87. https://doi.org/10.5937/GeoPan1602079S.

Tvaronavičienè, M., Prakapienè, D., Garškaitė-Milvydienė, K., Prakapas, R., Nawrot, Ł., (2018). Energy efficiency in the long-run in the selected European countries. Economics and Sociology, 10(2), 21-32. doi:10.14254/2071-789X.2017.

Ushakov, D., Akhmetova, S.G., Nevskaya, L. V. (2017). Economic growth and environmental performance: Correlation issues and future priorities. International Journal of Ecological Economics and Statistics, 38(4), 164-172.

Ushakov, D., Kharchenko, L. (2018). Environmental factors of national competitiveness in modern MNCs' development. International Journal of Ecological Economics and Statistics, 38(2), 141-149.

Webb, J. (2015). Improvising innovation in UK urban district heating: The convergence of social and environmental agendas in Aberdeen. Energy Policy, 78, 265-272. https://doi.org/10.1016/j.enpol.2014.12.003.

Werner, S. (2017). International review of district heating and cooling. Energy, 137, 617-631. https://doi.org/10.1016/j.energy.2017.04.045.

Wissner, M. (2014). Regulation of district-heating systems. Utilities Policy, 31, 63-73. https://doi.org/10.1016/j.jup.2014.09.001.

Wu, Y., Yu, Z., Ngan, H.W., Tan, Z. (2014). Sustaining China' s electricity market development. Energy policy, 73, 30-37. https://doi.org/10.1016/j.enpol.2014.05.043.

Zlyvko, O., Lisin, E., Rogalev, N., Kurdiukova, G. (2014). Analysis of the concept of industrial technology platform development in Russia and in the EU. International Economics Letters, 3(4), 124-138. https://doi.org/10.24984/iel.2014.3.4.2. 